Marquette University

e-Publications@Marquette

College of Communication Faculty Research and

Publications

Communication, College of

$1-1-2016$

\title{
Old New Media: Closed-circuit Television and the Classroom
}

Amanda Keeler

Marquette University, amanda.keeler@marquette.edu

Accepted version. Convergence: The International Journal of Research into New Media Technologies, Vol. 24, No. 6 (2018): 538-553. DOI. (C) 2018 by SAGE Publications. Used with permission. 
Old new media: Closed-circuit television and the classroom

\section{Amanda Keeler}

Writing about television for The New American Mercury in 1951, John Tebbel described what he called the 'bright promise stage' of new media — that small window of time in which users experiment with a new technology to discover ways that it might 'broaden our horizons' (235-36). Tebbel's bright promise stage concept illustrates how different groups attempt to locate and implement useful, beneficial, and profitable functions for new media technologies, with varying degrees of adoption and public recognition. Invariably, the emergence of a new media technology provokes discussions of its educational applications that are punctuated with deeply optimistic rhetoric touting its boundless future classroom potential. This recurring rhetoric exemplifies the profound power attributed to both education and new technology in the United States. As educational technology historian Larry Cuban notes, in the United States we have 'an enduring faith in the power of schools to make a better society,' and in order to accomplish this, 'public officials, corporate executives, vendors, policymakers, and parents' have often sought to employ new media technologies for classroom teaching purposes $(2001: 1,12)$. To this day formal education persists, at least symbolically, as the major mechanism of social and cultural uplift, credited with the ability to expand intellectual abilities and to increase personal fulfillment and wealth through better employment opportunities. This belief in the power of education intersects with the profound faith that many put in the promise of new technology to enhance, improve, and streamline existing practices.

Studying the 'bright promise stage' of new media offers an invaluable opportunity to explore the cultural milieu in which new technologies emerge. As Carolyn Marvin writes, 'the history of media is never more or less than the history of their uses, which always lead us away 
from them to the social practices and conflicts they illuminate' (1988: 8). To the historian, these 'social practices and conflicts' illustrate the promises but also the disruptions created by new technologies as they are introduced into existing spaces. Though Marvin uses this framework to situate her historical analysis of nineteenth century electrical communication, it helps to unpack the ripples that appear each time a new technology is called upon to fix or improve education. This paper investigates the 'social practices and conflicts' that emerged as a result of the introduction of closed-circuit television (CCTV) in the classroom. Though known today mainly for its surveillance capabilities, in the 1950s and 1960s educators experimented with CCTV as a low-cost classroom tool that could be used to facilitate in-house educational program creation and networked distribution in schools. Using period articles and advertisements from popular press magazines, educational journals, books, and archival materials, this essay argues that educators, reformers, and technology manufacturers framed closed-circuit television as an ideal new technology that would work to alleviate multiple educational concerns in the United States in the 1950s. Educators envisioned CCTV as a way for schools to move away from the commercial, profit-oriented national networks and allow them to create their own in-house school networks. Out of this faith in CCTV arose two Ford Foundation funded installations, the Hagerstown CCTV Project and the Chelsea Closed-Circuit Television Project, both of which attempted to showcase how administrators, schools, and teachers could utilize CCTV in the service of elevating both classroom teaching and student learning. However, despite the initial faith in this new technology, CCTV presented a series of challenges and issues that prevented its widespread adoption, including concerns about cost of the equipment and personnel training, the creation, distribution and exhibition of its programming, and its overall classroom effectiveness. CCTV's promotion for the classroom illuminates some of the larger conflicts at work when a 
new technology disrupts existing institutional practices, particularly pointing to whose or what version of education gets represented through these educational initiatives.

\section{Education and broadcasting}

By the late 1940s, teachers, school administrators, and cultural commentators saw television as a potentially powerful educational tool. For example, Jack R. Poppele, President of the Television Broadcasters Association, wrote that television 'may unlock the door to world understanding' (1948: 72). Edwin Adams, Associate Superintendent of Philadelphia schools, claimed that television 'would be the most efficient educational medium devised by man' (1949: 248). With the rapid growth of the broadcasting industry after World War II, it became imperative that those interested in educational television unite to reserve space on the electromagnetic spectrum for this purpose. As John Tebbel notes, 'Petitioners were obviously doubtful that education would get any better deal from television than it got from radio' (1951: 235). Between the popularity of entertainment programming, the commercial advertising financial model, and the prioritization of issuing licenses to commercial stations, educational programs in the 1930s and 1940s were given little space to air or flourish (Leach, 1983; McChesney, 1993; Smulyan, 1996; Streeter, 1996; Hilmes, 1997; Slotten, 2000 and 2009). Senator William Benton wrote that by the 1940s most educational radio programs 'had been kicked around by the networks, shifted again and again to new time periods, or killed' (1951: 8). In 1950 Newsweek claimed that 'from the time that television became a foreseeable reality, millions of words were spoken about the great public-service potentialities of the medium, particularly in the field of education. But the same words had been spoken of radio, and radio went overwhelmingly commercial' (90). Through a confluence of factors, education by radio 
failed to prosper in the way that many had envisioned, which inspired the supporters of education by television to redouble their efforts to prevent this from recurring. Groups such as the National Education Association, American Council on Education, Association for Education by Radio, National Association of Educational Broadcasters, and the National Council of Chief State School Officers formed an ad hoc committee, the Joint Committee on Educational Television, in the hope that they would be able to preempt a contentious battle between commercial and educational interests (1954 Report). These groups feared that commercial networks would dominate the television airwaves as they had with radio, sparking a lengthy conflict with the FCC, the group that had the authority to fulfill or deny special channel reservation requests (Barnouw, 1968, 1970; Brinson, 2002; Saettler, 2004). Thanks to the vocal support of Commissioner Frieda Hennock, the FCC eventually authorized the reservation of more than 200 channels for use by noncommercial, educational stations when it issued the Sixth Report and Order in 1952 (Reed, 1952: 230).

Hennock hoped that the 1952 Sixth Report and Order would prompt schools and communities to construct numerous noncommercial, educational television stations that would create programming tailored for local needs and perhaps alleviate problems such as teacher shortages. While Hennock was instrumental in ensuring space on the spectrum for noncommercial programming, only a handful of stations were formed in the years following, such as the University of Houston's KUHT in 1953, followed by Michigan State's WKAR and the University of Wisconsin Madison's WHA-TV, both in 1954 (Witherspoon and Kovitz, 2000: 12, 59). Starting a noncommercial television station required considerable financial resources for construction, equipment purchases and upkeep, program creation, and qualified personnel. The enormous cost for these items was beyond the means of many schools and communities that 
otherwise were eager to create and utilize television for education. According to School Review, the cost to open and equip a noncommercial television station was staggering, 'from $\$ 200,000$ upward' [\$1.774 million in 2016 dollars] $]^{1}$ (Hartung, 1953: 75). Hazel Cooley, author of the 1952 book The Origins and Potentialities of Educational Television, estimated that the total cost of equipment alone for one television station was closer to $\$ 450,000$ [ $\$ 3.71$ million in 2016 dollars], and that the cost to construct a station and run it for one year was nearly $\$ 600,000$ [\$5.364 million in 2016 dollars] (72-76). When the money to fund these ventures did materialize, it often came from private philanthropic sources such as the Ford Foundation.

While Hennock's vision of noncommercial, educational stations proved too costprohibitive for most communities, closed-circuit television provided a more affordable, alternative version of educational television that could cater to specific classroom and school needs. CCTV stood at the nexus of many of these concerns. It was ideally positioned to improve the quality of television and facilitate its use in schools, helping to create an in-house network tailored to specific school needs - with a much smaller price tag and free of the influence of the commercial networks. Unlike a television station that transmits programs for broad distribution, closed-circuit television instead delivers private, in-house, or internetwork transmissions. High school English teacher Stanley Solomon noted that CCTV is 'the type of teaching you do when you are separated from your students by hundreds of feet of coaxial cable. It is teaching by television that originates in your school and never leaves it' (1959: 5-T). Leslie P. Greenhill, Director of the University Division of Instructional Services at Pennsylvania State University, wrote that closed-circuit television would be most useful for the "presentation of regular classroom instruction to students located in multiple classrooms' (1966: 2). 
Much of the literature on CCTV for classroom use focused on the small amount of space and equipment necessary to create in-house, networked programming. At its most basic, CCTV required two separate elements: a studio space outfitted with a camera and classroom televisions to receive the signals. The studio space could be on or offsite and the program feed could be connected to the televisions via coaxial cable or over-air signals (Gumpert, 1969: 156). In the studio a teacher, speaker, or performer would deliver their lesson, which would be transmitted simultaneously to any number of other spaces designed to receive these programs. Stanley Solomon noted that the CCTV studio space at his school, Linton High, fit into what he described as 'half of a large classroom' (1959: 5-T). CCTV could also be utilized for 'two-way communication' that allowed the onscreen teacher to 'converse with their viewers' (Udell, 1955: 37-T). This meant that unlike generic educational programming broadcast from a local television station, teachers and administrators had the ability to craft specialized, in-house programming tailored to specific classroom needs with the potential for interactivity. This function of CCTV meant that schools could create a network across a school district, effectively producing educational programming outside the purview of the national networks, who as noted earlier had done little to demonstrate their interest in sustaining educational programs on radio.

The ability to send lessons to multiple classrooms resonated with a frequently cited advantage of media in the classroom: the concept of the master teacher, a person with expert knowledge on one or more subjects. Theoretically one scholar could productively teach hundreds of students at the same time by transmitting his or her lecture via a CCTV network to multiple classrooms. Senior Scholastic writer William Temple emphasized the potential reach of a televised master teacher and claimed that CCTV made it possible for multiple classrooms to watch simultaneously 'an expensive lecture-demonstration' (1949: 17-T). On the surface the 
prospect of having a teacher in one room deliver a lecture or demonstration to a camera while concurrently sending it to linked classrooms seemed unduly complicated and perhaps unnecessary, but many saw potential in the ability to bring experts to many students at once through this new technology. On a secondary level, a master teacher was one solution posited to help understaffed and overcrowded schools. According to United States Commissioner of Education Earl J. McGrath, there was an 'inadequate supply of properly educated teachers' (1953: 100). Other writers echoed this anxiety, including Robert Bendiner, a contributor to The New York Times, who wrote that the nation was at a 'moment when the shortage of teachers has become an acute worry and the costs of college a growing concern' (1953: SM9). The lack of qualified teachers posed problems for the rapidly shifting demographics of the period. In particular, the post-World War II 'baby boom' meant that elementary schools in 1953 would 'be called upon to enroll' approximately 1.691 million more students than they had only a year earlier (Bendiner, 1953: SM9). These shortages connected to another growing concern in the 1950s, the perceived educational gap between the United States and the Soviet Union, brought to the attention of millions when the Soviets launched Sputnik, the first artificial, earth-orbiting satellite, in October 1957. This technological feat prompted a wave of rhetoric that warned of the dire consequences for the US if it failed to produce and train sufficient numbers of scientists, engineers, and other technologically minded college graduates (Orgeron 2012: 424). For example, Norman Carlisle claimed that 'when Russia's first Sputnik raced around the earth last fall, its ominous beep-beep sounded an urgent call to expand our teaching of science, the very area where the teacher shortage is at its worst' (1958: 91). Carlos de Zafra, coordinator of general education at Charlotte High School in Rochester, New York, noted that since the postwar population surge had created a 'shortage of qualified, fully certified teachers, it could be an 
advantageous use of educational CCTV if a master teacher were to teach certain lessons to several classes simultaneously' (1957: 152).

The promotion of CCTV also detailed its operational ease. Gene Udell noted the simplicity of the equipment: 'the smallest and simplest closed-circuit television camera is about the size of a cigar box. Two sets of wires lead from it, one to the wall socket, and the other to the antenna terminals of the television receiver. Turn on the camera, turn on the receiver, and you have a television studio in your classroom' (1955: 37-T). The simplicity of the equipment was balanced by discussions of its low cost. Stanley Solomon noted that setting up CCTV for a school was much less expensive than building, equipping, and running an educational television station (Solomon, 1959: 5-T). To equip a school for CCTV, Solomon estimated that the 'average installation' costs would range from $\$ 5,000$ to $\$ 20,000$ [ $\$ 40,707-\$ 162,828$ in 2016 dollars] including special equipment such as 'TV receivers and special film projectors' (1959: 5-T). This fact was particularly evident in several advertising campaigns, which focused on the low cost of CCTV technology for the classroom. For example, a two-page Radio Corporation of America advertisement from January 1960 noted that it 'makes down-to-earth budget sense to turn to the world leader in electronics for the instructional aids teachers need and want' (6-7). Elgeet Optical Company’s December 1960 advertisement in Educational Screen emphasized its 'amazingly low prices' on equipment that schools could purchase 'for under $\$ 1,500$ ' $[\$ 12,005$ in 2016 dollars] (629). Sylvania’s January 1962 advertisement asked: 'Think private TV is out of reach for your school?' The company boasted that its Direct Wire TV system was 'so low in cost any school' could afford it (29). Bell Telephone System's May 1962 advertisement 'The ABC's of ETV' claimed that they had 'found low-cost ways to put Educational Television in the classroom' (249). 
CCTV also promised to elevate the teaching of certain subjects through its unique qualities. Proponents saw CCTV's utility in magnifying objects so that students could more closely see visual aids. As de Zafra noted, the CCTV cameras could 'focus upon quite small objects and areas so that many pupils in several classrooms can see the details of a demonstration better' (1957: 153). Additionally, it offered a solution to a long-discussed complaint of moving pictures in the classroom: the scarcity of film prints. Writers noted that the CCTV cameras could be used to send one moving picture to multiple classrooms. For example, Gene Udell, Associate Professor of Education and Director of the Audio-Visual Center for Temple University, noted that the Chicago Teachers College utilized closed-circuit television to send films 'by coaxial cable' to any number of connected classrooms (1955: 38-T). Stanley Solomon also reported that Linton High School in Schenectady, New York, had successfully screened educational moving pictures to multiple classrooms via CCTV (1959: 5-T).

Aside from the direct classroom education of students, CCTV was often cited for its perceived ability to train teachers, medical students, and military personnel. Gene Udell thought CCTV could be used to observe teachers and to create quantifiable data on "teaching effectiveness' (1955: 38-T). William H. Allen, Coordinator of Extension Television for the Bureau of Audio-Visual Instruction at the University of Wisconsin, claimed that CCTV was ideal for the pedagogical training of teachers. Allen felt that separating the teacher from evaluators allowed the classroom to be observed in an environment closer to its usual state (1953: 389). Using CCTV in medical training meant that students could watch skilled surgeons perform delicate procedures in small operating rooms from afar. Gary Gumpert, Professor of Communication Arts and Sciences at Queens College, wrote that military personnel could use CCTV to teach skills such as the 'disassembly of a machine gun' without requiring an instructor 
to be present (1969: 166). And to maximize the technology, Gene Udell noted that schools could use their CCTV facilities not only to create programs but also to facilitate hands-on training to prepare students to work in the television industry (1955: 38-T).

Many schools saw the 'bright promise' of educational television delivered via closed circuit. In February 1956 Senior Scholastic reported that there were around 60 'units in public school systems, colleges, universities and military installations,' and by 1962 this number had risen to 462 installations in 403 institutions (17-T). By 1966 Judith Murphy and Ronald Gross estimated that there were 'probably close to 1,000 closed-circuit installations serving educational purposes' (1966: 23). Though these figures speak to the large number of schools that were experimenting with CCTV, Gary Gumpert explained that it was difficult to verify exactly how many CCTV installations existed because they were not licensed with the FCC in the same way as commercial or noncommercial, educational television stations (1969: 155). So while these numbers were merely estimates, they suggest the proliferation of CCTV in educational settings.

\section{The Hagerstown and Chelsea closed-circuit television projects}

Two well-funded educational CCTV installations, the Hagerstown CCTV Project and the Chelsea Closed-Circuit Television Project, garnered widespread coverage in newspapers and magazines such as The New York Times and Educational Screen. The Hagerstown CCTV Project, so named for its location in Hagerstown, Maryland, began in 1956 with a five-year grant totaling \$1,013,910 [ $\$ 8.831$ million in 2016 dollars] from the Ford Foundation's Fund for the Advancement of Education, allocated to facilitate instructional television (Ford Foundation Report, 1976: 8-9). Overall, the Hagerstown Project used the grant to explore the possibilities and feasibility of teaching school-aged children with televisions in the classroom. At the 
Project's height, CCTV 'was used for the daily classroom instruction of nearly 18,000 students in Washington County' and incorporated a wide range of programs for students of all ages, with lessons on mathematics, languages, science, history, music, and art (Moody, 1993: 16; Progress Report 1959: 1).

Evidencing the elaborate nature of the Hagerstown Project, a number of external publications and companies joined forces to facilitate the overall structure of the CCTV installation. TV Guide published a 'school edition' that purported to keep both parents and students aware of the television programs that each grade would watch in their classes each week, and Bell Telephone Company 'designed and constructed' the coaxial cable network that linked the schools participating in the Hagerstown Project (50 Year Report, 2006: 2). Teachers who were already employed by local schools conceived much of the classroom CCTV programming and were able to focus on their strengths. As John Weiss wrote, 'A teacher whose particular specialty is visual aids and model-making may now concentrate on the preparation of charts and models. Or a teacher who is most talented in presenting material is no longer concerned with the chore of marking papers but concentrates on the half-hour TV presentation' (Weiss, 1957: 470).

In 1968 David Lyle authored the Washington County Closed-Circuit Television Report, highlighting many findings about the overall success and effectiveness of the Hagerstown CCTV Project. One section of this publication focuses largely on student, teacher, and parent reactions to the use of televisions in the teaching of science. Lyle notes that 'science instruction offers an example of the way television can be used to upgrade the curriculum' (1968: 1). In this regard, students generally felt positively about how television aided these types of courses. One student in a science class that utilized television reported that they 'like[d] the experiments we can do 
with our television teacher' (Lyle, 1968: 60). Another noted that 'Our teacher on television has all kinds of things we can't get for our classroom' (Lyle, 1968: 60). When asked the question, 'Do you think your pupils can learn more about science with television or without television?' the Report noted that $92 \%$ of teachers felt that television served as a useful classroom aid (Lyle, 1968: 61). The comments from parents were generally positive as well, though only $65.9 \%$ reported that they preferred television be included in their children's science instruction. This lower number is explained by some of the parents' comments included in the Report, from 'I don't think she learns as much with television' to 'He has learned to become interested in living things now' (Lyle, 1968: 62). Overall, Lyle's Report focused heavily on the assets television brought to science education, while noting that other subjects, such as reading, were not served as readily by television teaching (1968: 54).

In 1976 the Ford Foundation published a report, Ford Foundation Activities in Noncommercial Broadcasting, 1951-1976, which noted that 'the experiment indicated that students learned classroom material presented on television as well as they would have learned the same material had it been presented by a classroom teacher' (Ford Foundation Report, 1976: 9). While it reported this mostly positive summary of the Hagerstown Project, the Ford Foundation declined to extend its financial involvement in the project funding after 1961. The project continued, but as the Foundation's money dissipated the project became untenable due to ongoing costs, such as the $\$ 142,000-\$ 150,000$ [ $\$ 1.125-\$ 1.188$ million in 2016 dollars] annual rental fee that the Project paid to lease the Bell Telephone System coaxial cables (Lesher, 1962: 109; 50 Year Report, 2006: 4). These costs resulted in complaints by local taxpayers concerned about the price of the project and the quality and necessity of the programs. Despite its high costs, the Hagerstown Project continued to create and distribute programming through the 1960s, 
and by 1966 it reported that over 84,000 students were 'receiving some instruction via television' (Gumpert, 1969: 172). In 1974 the Project shifted its distribution model when it ceased sending CCTV programs over cable and began to focus on maintaining a videotape library of classroom lessons that could be mailed to interested schools (50 Year Report, 2006: 26).

While the Hagerstown Project's overall mission was to explore ways to use new technology to reach students in classrooms, another CCTV project instead sought to expand the world of education to people both inside and outside of traditional classrooms. The Chelsea Closed-Circuit Television Project, so-named for its location in the Chelsea neighborhood of New York City, ran from 1957 to 1961. Like the Hagerstown Project, the Chelsea Project was funded by a multiyear grant from the Ford Foundation with additional sponsorship from a number of groups, including the New York City Board of Education, Harvard University's Language Research, and the Hudson Guild Neighborhood House (Chelsea Report, 1962: 1). The Chelsea Project's overall mission was to 'explore the values of closed-circuit television as a service to a low-income, poly-lingual, urban neighborhood and its public school' by sending programs 'to the school and to the residents of a public housing unit' (Chelsea Report, 1962: 1). The program was unlike other school-based CCTV installations in that it sought to reach city dwellers by 'interconnecting' not only schools but also 'homes, and health and social services' (Gumpert, 1969: 172-73). Its primary goal was to teach English through a variety of television programs to the 'multilingual' Spanish-speaking Puerto Rican residents living in the John Lovejoy Elliott Houses public housing complex. In the late 1950s the Chelsea CCTV network offered programs such as Teamwork for Child Health, a health education program for families, Spotlight on Chelsea, which featured local neighborhood issues, and a children's variety program called The Friendly Giant (Chelsea Report, 1962: 9-16). By the 1959-60 school year the project retooled its 
programming in response to rapidly declining viewership (Chelsea Report, 1962: 32). From that point forward it offered considerably fewer programs overall, most of which were lighter entertainment fare, such as the cooking show The Recipe Box and the children's program Elise in Wonderland (Chelsea Report, 1962: 34).

After the Chelsea Project ended in 1961, the New York Board of Education published its findings in Closed-Circuit Television: A Report of the Chelsea Project. This data-driven publication surveyed the stated goals of the project, its different community and school programming, student learning assessments, and overall reactions to the five-year project. The publication reports that teachers were satisfied with the "varied materials, standards of instructional procedures' and 'well-integrated programs,' but many felt that it was largely a futile exercise that created more problems than it solved (Chelsea Report, 1962: 233). Many of the teachers working for the Chelsea Project found it difficult to manage the dual workload of their television teaching and their own classrooms. They also responded that their students appeared to be 'somewhat bored with TV lessons' (Chelsea Report, 1962: 233). Additionally, the staff assumed incorrectly that the residents of the John Lovejoy Elliott Houses, the public housing complex where the experiment took place, would welcome the Chelsea Project's programs with 'gratitude.' Instead, the staff reported that 'they were unprepared for a groundswell of suspicion and resentment' over equipment issues and the perceived intrusion into private residences and non-work leisure time (Chelsea Report, 1962: 141, 146). Further, while the Chelsea Project's stated mission was 'to promote good citizenship' and English language skills, some residents read the inclusion of programs such as 'So You Want to Get A Job' as not-quite-coded commentary on the perception of the people living in the housing project (Chelsea Report, 1962: $2,146)$. 
In the Chelsea CCTV project, the inclusion of programs such as 'So You Want to Get A Job' speaks to one important aspect of education by television-whose or what version of education gets represented through these educational initiatives. CCTV and other educational television experiments had lofty goals - to better educate young people in classrooms, to reach adults in their homes who wanted to expand their formal education, and to improve overall the types of programs available for all audiences on commercial television (Smythe, 1951). These CCTV experiments also allowed schools and private foundations to create their own networks of programming they deemed educational. Yet, as Laurie Ouellette argues, it is important to remember that educational television 'did not emerge from popular demand' but rather by 'private foundations, reformers, and educators hoping to rescue television from the ravages of commercial entertainment' (2002: 41). The Ford Foundation, she writes, 'envisioned television as a conduit for culture and adult education, a vision accountable not to the public but to the priorities established by its white, male, upper-class trustees' (Ouellette, 2002: 42). In addition to being the major financial contributor to the Hagerstown and the Chelsea Closed-Circuit Television Projects, the Ford Foundation had also experimented with culturally uplifting commercial television programming with Omnibus (1951-56), 'designed to promote classical music, dance, literature, drama, philosophy, history, and science' and would put significant funds in support of National Educational Television (NET), the precursor to what would later become the government backed Public Broadcasting Service (PBS) (Ouellette, 2002: 43; Avery and Pepper, 1979; Blakely, 1979; Day, 1995; Witherspoon and Kovitz, 2000). As Ouellette notes, 'National Educational Television valorized the sophisticated, college-educated, intellectually oriented, implicitly white minority who protested television's cultural mediocrity while engaging its upwardly mobile aspirants in a pedagogic and frequently disciplinary relationship' (2002: 45). 
The Ford Foundation was able to use its financial backing as a tool to shape programming and curricula that would instill in viewers the Foundation's vision for idealized citizens. In this way, the Ford Foundation functioned largely as a 'master teacher' in shaping educational television in the 1950s and 1960s. The Foundation used its considerable financial means to support the subjects and outcomes it considered the most vital to its educational mission, which may or may not have been connected what television viewers at home wanted, or what students and schools needed (de Zafra, 1957: 152; Ouellette, 2002; McCarthy, 2010).

\section{Problems with CCTV}

The Hagerstown and Chelsea CCTV Projects demonstrate the 'conflicts' and disruptions created by one new technology, CCTV, as school districts sought to improve and expand existing classroom spaces. Despite the initial thoughts that CCTV could provide schools with a low-cost way to deliver networked classroom television, the Hagerstown Project's overall high cost contributed to its eventual shuttering. Likewise, the Chelsea CCTV Project folded much of its programming after the Ford Foundation removed its funding. Indeed, these two CCTV projects fulfilled a prophecy expressed in Robert Lewis Shayon's 1959 article 'How Valuable is Video?' Shayon quotes a teacher who notes that 'the whole experiment in mass TV teaching across the country would collapse' without the Ford Foundation's financial support (21). In the case of these two prominent CCTV projects, this premonition proved correct. In their 1976 Report, the Ford Foundation notes that 'In the late 1950s the support required for instructional television became too great for the resources of the fund,' which forced the Fund to suspend its financial support for large-scale instructional television initiatives (8). 
It was not just the removal of the Ford Foundation's support that signaled the end to CCTV classroom experiments. A host of other issues and concerns plagued the technology and prevented its widespread classroom adoption. For one, aside from the support in magazines such as Educational Screen, many educators continued to believe that CCTV was not an ideal technology for school use. Addressing statements that promoted CCTV use to alleviate understaffed schools, Dr. Sherwin Swartout, a Supervisor for the Brockport State Teachers College CCTV project, claimed that 'educational television does not cut down on the number of teachers required' because of the need for additional trained personnel to install, run, and maintain the equipment (de Zafra, 1957: 153). For example, David Lyle's 1968 Report on the Hagerstown CCTV Project listed the large number of full and part-time personnel needed to maintain this installation, including one coordinator, one instructional supervisor, a teaching staff of 25 , a production staff totaling 30 people, an engineering staff of eight, and seven staff members across art and clerical duties (11). These trained workers cost money—the very thing that this technology had originally promised to save. As well, CCTV technology was not nearly as simple, user-friendly, or affordable as its proponents suggested, when in fact only specialized personnel could properly operate the equipment. Though touted in many advertisements as lower-cost, its purchase and upkeep was still a significant expenditure. For example, in 1958 Business Week published several articles as part of a special report titled, 'What's Being Planned for Tomorrow's Schools?' (74-78). The section featured a photograph that showed a large number of students in an auditorium with fixed seating, watching a man speak on eight different television sets interspersed throughout the space. This photograph illustrates that while the cost of an individual television set for the classroom was a fixed, minimal cost, the small size of 
televisions necessitated having multiple sets in spaces such as this large classroom, thus multiplying this cost dramatically.

The expense of CCTV raises some important questions about the relationship between classroom technology and cost. Within the recent wave of scholarship on the educational use of media, surprisingly little work has focused on the business side of these ventures and their potential profitability. New technologies are developed and marketed by companies with a vested financial interest in maximizing multiple future uses, either as educational objects or any other use that proves profitable (Tyack and Hansot, 1985; Singer, 1988; Saettler, 1990; Cuban, 2001; Solbrig, 2012). The recurring aspiration to put new media technologies to use in the classroom perpetuates a cycle of high tech remedies that play on fears over the future of education in the United States, as CCTV had done with concerns over baby boom era school populations and post-Sputnik science education. Historian Paul Saettler describes this phenomenon as the 'media bandwagon syndrome,' during which idealized notions about new media technologies are 'superimposed on the educational system implying that existing educational ills or problems can be cured by the use of this new medium or mode of technology' (2004: 404-405). Classroom technologies such as CCTV often do not succeed in transforming education, or in creating alternative, noncommercial networks, but they do create temporary new markets and profits for companies with a financial stake in each new technology being promoted and sold for classroom use.

In the case of the Hagerstown Project, after the Ford Foundation ended their funding, local officials had a hard time convincing taxpayers that the project warranted the hundreds of thousands of dollars a year to lease the coaxial cables from Bell Telephone Company, which featured the Hagerstown CCTV Project in its advertisements. For example, in the May 1962 
issue of Educational Screen, Bell's full-page advertisement quoted Robert F. Lesher, Coordinator of the Hagerstown Project, who stated that 'In the Hagerstown experiment, we found we could rely on the local Bell Telephone Company's facilities and knowhow to put the highest picture quality in our classrooms' (1962: 249). The amount of money that the Hagerstown Project paid for the coaxial rental fees, coupled with the use of the Hagerstown Project in its advertisements, demonstrates that Bell had a tremendous financial stake in promoting CCTV projects as successful educational experiments while also sustaining those already in existence. Additionally, educational journals and magazines such as Educational Screen continued to publish glowing accounts of the CCTV experiments through articles and editorials, which ran alongside a range of advertisements for the very same educational products and services from Bell Telephone System, Magnavox, Ampex, RCA, Sylvania, Kodak, and many others. These companies, regardless of the viability or longevity of the equipment they were building and selling, were positioned to make millions of dollars if they could successfully expand their markets into classrooms around the country.

Beyond the monetary cost of the CCTV equipment, the technology also changed the human labor costs as well. As noted earlier, John Weiss claimed that one of the major advantages of teaching via CCTV was that teachers only had to prepare one lesson a day and thus were able to devote all of their preparation time to crafting well-thought out materials that could focus on their particular strengths (Weiss, 1957: 470). Like many of the idealized assumptions of the benefits of using technology to play to particular teachers' strengths in education, comments such as these tended to overlook the realities of preparing lessons for television. In the May 1958 Washington County Board of Education Report one respondent commented that 'the amount of reteaching I do in television is much greater. In fact, there is often not enough time in the follow- 
up to do the scheduled work and the reteaching needed' and that it required 'more time' to prepare the lessons (1958 Survey: 1). Though Weiss saw the television presentation as less time consuming, some of the Hagerstown teachers found it to be the opposite. Additionally, these teachers were being asked to perform for television — something vastly different and far outside of the training they received for classroom teaching (Smith, 2014).

While teachers seemed to be spending more time to facilitate the classroom technology, CCTV also played into the persistent anxiety that teachers were being asked to utilize and embrace the technology that might prove to replace them. Writers like Edward Stasheff saw the benefits of education via television, but he acknowledged that television was 'sometimes pictured as a mechanical monster that will throw thousands of teachers out of work, or as a mass production method, turning out standardized schooling and interchangeable scholars' and that it had 'not yet solved the problems of individual differences; personal counseling; [and] pupilteacher interaction' (1959: 13T). He was not the only one to note these fears. Vivian Powell, President of the National Education Association Department of Classroom Teachers, wrote that 'much of a child's learning comes from interaction between pupil and teacher,' something that a television in the classroom could not provide (1957: 506). William Levenson, Assistant Superintendent of Schools in Cleveland, Ohio, commented that it was important to remember that television 'can never replace the human personality in the classroom' (1953: 562). He stressed that the personal relationship that was fostered between students and teachers was an important factor in helping children learn and prosper. As both supporters and critics of CCTV pointed out, if television was to be used in the classroom to enhance the learning of children, merely replacing teachers with televisions was not an ideal application of this new technology (Costello and Gordon, 1961: 24-40). Yet, in many ways, the promotion of CCTV promised to do 
exactly this - transmit teachers via coaxial cable to classroom televisions, displacing them from the personal interaction with their students.

The costs and questions of profit were just two of many obstacles that challenged the idea that CCTV was an ideal classroom technology. The transient nature of its broadcasts presented a significant drawback as well. Gary Gumpert noted that 'before 1956 one of the problems which surrounded the efficient utilization of closed-circuit television was the lack of an adequate and economical recording capability' (1969: 174) While some CCTV setups were equipped with kinescopes, devices that recorded programs onto film from a television monitor, most schools did not possess this recording capability. For example, most of the Hagerstown lessons during the first several years of the Project were delivered live and not recorded. According to the Project's '50 Year Report,' it wasn't until 1958 when the Ampex Corporation donated one videotape machine that Hagerstown had the equipment to record and distribute of these television lessons, enhancing the availability of this closed-circuit television project's vast offerings (50 Year Report, 2006: 2; Snively, 1960: 226-28). The growing availability of videotape by the late 1950 s promised to rectify this issue. Videotape became a 'means for recording and immediate playback with the impact of a live transmission,' allowing schools to create libraries of educational materials (Gumpert, 1969: 175; Miner, 1959: 531; Brown, 1959: 528).

Many of the positive articles about CCTV in magazines such as Educational Screen discuss the potential learning that might result from televisions in the classrooms, yet they rarely center on the effectiveness of the technology or on actual measured learning outcomes. As Larry Cuban notes in his 2001 book study of computers in the classroom, Oversold and Underused, 'the billions of dollars already spent on wiring, hardware, and software have established the 
material conditions for frequent and imaginative uses of technology to occur. Many students and teachers have acquired skills and have engaged in serious use of these technologies. Nonetheless, overall, the quantities of money and time have yet to yield even modest returns or to approach what has been promised in academic achievement, creative classroom integration of technologies, and transformations in teaching and learning' (189). Cuban presented these findings after an intensive study of schools in Silicon Valley, much like the post-Chelsea CCTV study presented in the 1962 publication Closed-Circuit Television: A Report of the Chelsea Project. Like Cuban, the Chelsea report found that 'there was no statistically significant evidence that, under the conditions of the experiment, the inclusion of televised lessons in the instructional program furthered the children's growth in knowledge of science or in understanding of languages' (Chelsea Report, 1962: 321). As David Tyack and Elizabeth Hansot demonstrate, these educational experiments with new technology follow a predictable path. The beginning excitement is replaced by disappointing results, with an interchangeable new media technology in the middle. 'Too often,' Tyack and Hansot write, 'inflated promises have been followed by a burst of enthusiasm and partial implementation, and then by discouragement and disrepair, broken morale and broken machines' (1985: 40).

The lack of demonstrable effectiveness has not stopped the promotion of new media technologies for the classroom post-CCTV. As Larry Cuban's study of classroom computers suggests, these types of technological, educational experiments have continued into the present day, yet the actual classroom application continues to complicate simplistic rhetoric that seeks only to heap praise on the endless learning potential of new technologies. Mirroring the Hagerstown CCTV Project, tablet computers such as the iPad continue to dominate the discourse as the current 'revolutionary' classroom teaching technology destined to enhance learning (Hu, 
2011; Gallagher et al., 2015). Following an alternative education distribution model, Massive Open Online Courses (MOOCs) provide an interesting parallel to the Chelsea CCTV Project's goal of reinventing and re-imagining the very idea of a classroom with a 'master teacher' at the helm (de Zafra, 1957: 152; Castillo et al., 2015).

While each new technological object (iPad) or learning space (MOOCs) has attempted to alleviate the problems associated with the production, distribution, and exhibition of educational materials, these newer experiments still demand that students have the opportunity to attend schools with access to new technology, have home-based high speed internet, or even electricity. Much like CCTV, these newer, better classroom tools have not yet solved the issues that remain roadblocks to their universal, widespread acceptance and availability. Despite the time separating the mid-century CCTV experiments and the introduction of the iPad, little has changed with regard to rethinking new technology and its ability to transform classroom spaces. Even with a clear record of each new technology's failure to fundamentally change or reform US classrooms or education, these conversations remain remarkably similar. Highlighting the 'social practices and conflicts' in the case of implementing new technologies to improve education in the classroom suggests that we are incorrectly approaching the task of improving education (Marvin, 1988: 8). As James Carey and John Quirk write, what is really at stake is not 'book versus computer in education but an adequate curriculum,' a much more complex and potentially less financially profitable endeavor (1970: 424).

\section{Conclusion}

This essay has explored CCTV as a case study of a technology that was marketed as a low-cost, in-house network of educational television programs as an alternative to more 
expensive options. Classroom technologies such as CCTV have a long record of uneven results, particularly after the 'bright promise stage' fades away. As I noted earlier, CCTV was merely one technology of many that have been touted as having the potential to revolutionize classrooms and learning. Many writers in the 1950s and 1960s attempted to convince readers that CCTV could alleviate some of the perceived problems in the American educational system, such as understaffed and overcrowded classrooms. With the passage of time, educational technology experiments such as CCTV appear as nothing more than recurring panaceas rooted in the everpresent but shifting concerns that American students are falling behind their peers around the world. Over the past two decades the rhetoric has continued to resonate with Sputnik-era calls for classroom media to keep American students from falling behind in math, science, and engineering. These fears were tied, even by the 1950 s and certainly by the 2000 s, to an increasingly globalized marketplace of ideas that threatened to destabilize the United States, avoidable only through continued improvements to education. These concerns continue to this day in the US, filtered into the calls for science, technology, engineering, and mathematics (STEM) studies in schools to be facilitated through high-tech, hands-on learning methods (Parker and Lazaros, 2014).

While I have highlighted only a few of the factors that continue to drive the experimental uses of new media technologies for educational purposes, I have tried to elaborate on some of the 'social practices and conflicts' that continue to inspire the discussion and promotion of new media technologies for classroom use (Marvin, 1988: 8). Inevitably the 'bright promise stage' of new media technologies fades away when these new media become old media. Yet, these moments still remain rich historical subjects to be mined because they provide insight into contexts in which they emerge. Likewise, as long as these cycles continue, scholars can look to 
them to understand better the contemporary environment that dictates each quick fix over more substantive reform measures.

The work in this essay is not meant to suggest a wholly pessimistic tone regarding classroom technology. Not every technology has been considered a failure; it is worth remembering that the textbook was once upon a time 'new media' in the classroom. Historical studies such as this one emphasize that the context of new technology will always be in flux, thus necessitating the continued study of these new technologies as they are marketed as 'quick fixes' for complex issues that extend well beyond the classroom.

Notes

${ }^{1}$ All 2016 dollar amounts are calculated using the United States Department of Labor-Bureau of Labor Statistics Consumer Price Index Inflation Calculator. http://data.bls.gov/cgibin/cpicalc.pl

\section{$\underline{\text { References }}$}

50 Year Report. Educational Television Reunion of the Washington County Closed Circuit Television System 2006. From the Hagerstown Project Archive at the Western Maryland Room Washington County Free Library Hagerstown Maryland (accessed June 2013).

Adams E (1949) The Philco Program of Education by Television. School \& Society, 2 April, 247-48.

Allen W (1953) Testing TV for Teaching Training. Educational Screen 32: 389-91, 408-409. Avery RK and Pepper R (1979) The Politics of Interconnection: A History of Public Television as the National Level. National Association of Educational Broadcasters.

Barnouw E (1968) The Golden Web. New York: Oxford University Press.

Barnouw E (1970) The Image Empire. New York: Oxford University Press.

Bell Telephone System Advertisement (1962) Educational Screen 41: 249.

Bell Telephone System Advertisement (1962) Educational Screen 41: 301.

Bendiner R (1953) If TV Moved Into the Classroom. The New York Times, 8 March, SM9, SM49-SM51.

Blakely RJ (1979) To Serve The Public Interest: Educational Broadcasting in the United States. Syracuse: Syracuse University Press.

Brinson SL (2002) Person and Public Interests: Frieda B. Hennock and the Federal Communications Commission. Westport: Praeger. 
Brish WM (1965) Eight Years of Instructional Television in Washington County. Journal of the SMPTE, February, 161-66.

Brown JW (1959) Videotape: Its Promise for Education. Educational Screen 38: 526-30.

Carey JW and Quirk JJ (1970) The Mythos of the Electronic Revolution. The American Scholar (Summer 39:3): 395-424.

Carlisle N (1958) Push-button Pedagogy. Coronet, April, 90-94.

Castillo NM, Lee J, Zahra FT, and Wagner DA (2015). MOOCs for Development: Trends, Challenges, and Opportunities. Information Technologies \& International Development 11(2): 35-42.

Closed-Circuit Television: A Report of the Chelsea Project (1962). New York Board of Education Fund for the Advancement of Education.

Cooley H (1952) The Origins and Potentialities of Educational Television. New York: Channel Press Publishers.

Costello LF and Gordon GN (1961) Teach with Television: A Guide to Instructional TV. New York: Hastings House Publishers.

Cuban L (2001) Oversold and Underused: Computers in the Classroom. Cambridge: Harvard University Press.

Day J (1995) The Vanishing Vision: The Inside Story of Public Television. Berkeley: University of California Press.

De Zafra C (1957) Some Pros and Cons of CCTV. The Clearing House, November, 152-54.

Elgeet Advertisement (1960) Educational Screen 39: 629.

ETV Story (1956) Senior Scholastic, 2 February, 17-T.

Ford Foundation Activities in Noncommercial Broadcasting, 1951-1976 (1976). New York: Ford Foundation.

Gallagher, TL et al. (2015) International Perspectives on Literacy Learning with iPads. Journal of Education 195(3): 15-25.

Greenhill L (1966) Closed Circuit Television for Teaching in Colleges and Universities. University Division of Instructional Services Pennsylvania State University. January.

Gumpert G (1969) Closed-Circuit Television in Training and Education. In: Koenig AE and Hill RB (eds) The Farther Vision: Educational Television Today. Madison: University of Wisconsin, pp. 155-82.

Hartung ML (1953) Educational TV. School Review, February, 74-76.

Hennock F (1950) TV 'Conservation.' The Saturday Review, 9 December, 22-23.

Hilmes M (1997) Radio Voices: American Broadcasting, 1922-1952. Minneapolis: University of Minnesota Press.

Hu W (2011) Math That Moves: More Schools Embrace iPad as Learning Tool. The New York Times, 4 January.

Joint Committee on Educational Television (1954). Two Years of Progress in Educational Television, September.

Leach EE (1983) Tuning Out Education: The Cooperation Doctrine in Radio, 1922-38. Current, August, pp. 2-19.

Levenson WB (1953) TV in the Classroom. Journal of the National Education Association, February, 562.

Lesher R (1962) The Hagerstown Story. In Dreyfus LS and Bradley WM (eds) Televised Instruction. Detroit: Wayne State University. 
Lipsyte R (1963) TV Goes CC. The New York Times, 7 April, 157-60.

Lyle D (1968) Washington County Closed-Circuit Television Report. Hagerstown, Maryland: Washington Board of Education.

Marvin C (1988) When Old Technologies Were New: Thinking About Electronic Communication in the Late Nineteenth Century. Oxford: Oxford University Press.

Mayers MA and Chipp RD (1957) Closed Circuit TV System Planning. New York: John F. Rider Publisher Inc.

McCarthy A (2010) The Citizen Machine: Governing by Television in 1950s America. New York: The New Press.

McChesney RW (1993) Telecommunications, Mass Media, and Democracy: The Battle for the Control of U.S. Broadcasting, 1928-1935. New York: Oxford University Press.

McGrath E (1953) Crucial National Problems in Education. School Life, April, 99-101, 106-107, 110-11.

Miner RA (1959) The Videotape Recorder. Educational Screen 38: 531-32.

Moody KC (1993) The Children of Telstar: A History of Media Shift in the Schools. PhD Thesis, Columbia University.

Murphy J and Gross R (1966) Learning By Television. New York: Fund for the Advancement of Education.

Norris C and Armstrong G (1999) The Maximum Surveillance Society: The Rise of CCTV. New York: Berg Publishers.

Orgeron M (2012) A Decent and Orderly Society: Race Relations in Riot Era Educational Films 1960-70. In: Orgeron D, Orgeron M, and Streible D (eds) Learning With The Lights Off. Oxford: Oxford University Press, pp. 424-41.

Ouellette L (2002) Viewers Like You? How Public TV Failed the People. New York: Columbia University Press.

Parker J and Lazaros EJ (2014) Teaching $21^{\text {st }}$ Century Skills and STEM concepts in the Elementary Classroom. Children's Technology \& Engineering 18(4): pp. 24-27.

Poppele JR (1948) Television: The Infant Grows Up. Time, 24 May, 72.

Powell V (1957) Here's How Teachers Look at TV. Journal of the National Education Association, November, 506.

Progress Report (1959) Closed-Circuit Television Teaching in Washington County 1958-1959. The Board of Education Hagerstown Maryland.

Radio Corporation of America (RCA) Advertisement (1960) Educational Screen 39: 6-7.

Reed PC (1952) Educational Reservation. Educational Screen 31: 230.

Saettler P (1990) The Evolution of American Educational Technology. Greenwich: Information Age Publishing.

Shayon RL (1959) How Valuable is Video? The Saturday Review, 14 February, 21.

Singer B (1988) Early Home Cinema and the Edison Home Projecting Kinetoscope. Film History 2: 37-69.

Slotten HR (2000) Radio and Television Regulation: Broadcast Technology in the United States. Baltimore: Johns Hopkins University Press.

Slotten HR (2009) Radio's Hidden Voice: The Origins of Public Broadcasting in the United States. Champaign: University of Illinois Press.

Smith J (2014) Dr Frank C. Baxter, Titan of US Educational Television. Screen 55(2): 189-203. 
Smythe DW (1951) An Analysis of Television Programs. Scientific American, June, 15-17. Smulyan S (1996) Selling Radio: The Commercialization of American Broadcasting, 19201934. Washington, D.C.: Smithsonian Institution Press.

Snively PC (1960) Tape Recorded Teaching at Hagerstown. Educational Screen 39: 226-28. Snow JE (1910) The Workingman's College. Moving Picture World, 27 August, 458.

Solbrig H (2012) Dr. ERPI Finds His Voice: Electrical Research Products Inc. and the Educational Film Market 1927-1937. In: Orgeron D, Orgeron M, and Streible D (eds) Learning With The Lights Off. Oxford: Oxford University Press 2012, pp. 193-214.

Solomon S (1959) Coaxial Teaching. Senior Scholastic, 15 May, 5-T.

Stasheff E (1959) Can Television Help Solve the Teacher Shortage? Yes! Senior Scholastic, February, 13T.

Streeter T (1996) Selling the Air: A Critique of Policy of Commercial Broadcasting in the United States. Chicago: University of Chicago Press.

Sylvania Advertisement (1962) Educational Screen 41: 29

Sylvania Advertisement (1962) Educational Screen 41: 584.

Tebbel J (1951) What Hath Two Billion Dollars Wrought? New American Mercury, February, 235-38.

Temple WJ (1949) And Now Television. Senior Scholastic, 2 February, 17-T.

Tyack D and Hansot E (1985) Futures that Never Happened: Technology and the Classroom. Education Week, 4 September, 35, 40.

Udell G (1955) CCTV-What Is It? Senior Scholastic, 6 October, 37-38-T.

Washington County Board of Education Report: Survey of Classroom Teachers Teaching with the Aid of Television (1958). May.

Weiss J (1957) Teaching by Television in Hagerstown. The School Review, Winter, 466-73.

What's Being Planned for Tomorrow's Schools? (1958) Business Week, 26 April, 74-78.

Witherspoon J and Kovitz R with Avery RK and Stavitsky AG (2000) A History of Public Broadcasting. Updated edition. Washington, D.C.: Current-The Public Telecommunications Newspaper. 